\title{
Insider Trading by Intermediaries: A Contract Remedy for Acquirers' Increased Costs of Takeovers
}

\author{
Jeanne M. Hauch
}

In the past two years, Wall Street has been shaken by a series of scandals in which investment bankers and lawyers have been charged with illegally trading in securities and tipping others about corporate takeovers planned by their own clients. ${ }^{1}$ Trading in a target ${ }^{2}$ company's stock by intermediaries, ${ }^{3}$ such as investment bankers and lawyers, prior to the public announcement of a tender offer or merger can drive up the price of the target shares, thereby making the acquisition more difficult and less prof-

1. The Wall Street scandals have mushroomed into more than a dozen government enforcement actions and an increasing number of private suits, involving hundreds of millions of dollars in damages. See infra note 38. In May 1986, the first defendants were charged with insider trading: Dennis B. Levine, a managing director at the investment banking firm of Drexel Burnham Lambert; Michael David, an attorney at the law firm of Paul, Weiss, Rifkind, Wharton \& Garrison; Martin Shapiro, a stockbroker; and Andrew Solomon, an analyst at an arbitrage firm. In July 1986, two former investment bankers at Lazard Frères and Shearson Lehman Brothers and a takeover lawyer at Wachtell, Lipton, Rosen \& Katz were accused of exchanging confidential information with Mr. Levine. All defendants, except Michael David, pled guilty to at least some of the charges against them. The real bombshell landed in November 1986, when Ivan Boesky, Wall Street's most successful arbitrager, paid a $\$ 100$ million penalty for trading on inside information supplied by $\mathrm{Mr}$. Levine and pled guilty to a criminal charge. In February 1987, Martin Siegel, a prominent managing director at Drexel Burnham, pled guilty to insider trading and agreed to cooperate with the government. That same month, three additional Wall Street figures-a Goldman, Sachs partner, a former official at Merrill Lynch, and a Kidder, Peabody vice president-were charged with a conspiracy to exchange information that allegedly earned the participants millions of dollars in illegal profits. These last three indictments have been dismissed voluntarily and the government has indicated that it plans to seek new indictments based on the same facts in the near future. Coll, Judge Asked to Probe Leaks in Insider Case, Wash. Post, June 5, 1987, at F2, col. 2; see Crudele, Fallen Deal Maker Regarded As Top Corporate Protector, N.Y. Times, Feb. 14, 1987, at 1, col. 2; Stewart \& Hertzberg, Inside-Trading Scandal Implicates High Aides at Goldman, Kidder, Wall St. J., Feb. 13, 1987, at 1, col. 6; Lewin, Some Assert S.K.C. Pushes Law Too Far, N.Y. Times, July 21, 1986, at D1, col. 2.

2. A "target" is a company that is the object of a tender offer or merger proposal by an "acquirer" company that seeks control of the target through the acquisition of shares of target stock.

3. Intermediaries include investment banks, law and accounting firms, printers, and public relations firms hired by corporations to facilitate corporate control transactions. This Note focuses on the role of investment banks, although the analysis may be applied to other intermediaries as well. 
itable for a potential acquirer. ${ }^{4}$ This Note argues that an acquirer who entrusts confidential information to an intermediary should recover damages from the intermediary firm for breach of contract when insider trading by the firm's agents based on the confidential information increases the cost of the takeover. ${ }^{.}$This cause of action will effectively compensate injured acquirers who have engaged an intermediary to perform services, encourage greater supervision of employees by intermediaries and deter insider trading.

This Note first explains why an acquirer whose confidential information is misused by an agent of the intermediary should recover from the intermediary for the higher costs of a takeover. Section II outlines how the acquirer may use a common law breach of contract theory to hold the employer of the inside trader liable. Finally, Section III discusses how the acquirer can demonstrate causation and prove damages with reasonable certainty under the proposed contract remedy.

\section{The Impact of Insider Trading on Acquirers in Corporate TAKEOVERS}

\section{A. The Problem}

The growing number and increased value of merger and acquisition transactions $s^{6}$ has created opportunities for large, quick profits from insider trading. ${ }^{7}$ To complete a tender offer, an acquirer may purchase the stock of a target, usually by paying a substantial premium over the market price of the target shares before the announcement of the takeover. ${ }^{8}$ The success

4. See infra notes $60-73$ and accompanying text.

5. The following discussion assumes that the leak of information has not been authorized by the client acquirer. See infra note 73 . If insider trading by intermediaries has caused the price to rise so much that the deal becomes prohibitively expensive and is aborted, the acquirer might assert a claim that breach of contract deprived it entirely of a business opportunity; however, the extremely speculative nature of these damages would probably preclude significant recovery.

6. The number of completed deals, including mergers, acquisitions, and leveraged buyouts increased from 1,526 in 1975 to 3,165 in 1985 . The sum of the total dollar values paid in disclosed transactions rose from $\$ 34$ billion in 1975 to $\$ 139$ billion in 1985.20 MERGERs \& AcQuistTIONS 45 (May/June 1986). This trend continued in 1986, when the number of corporate mergers rose $12 \%$ over the level of 1985, Corporate Mergers Climbed 12\% for 1986, Grimm Says, Wall St. J., Feb. 11, 1987 , at 15, col. 1, and takeover activity was robust for the first half of 1987. Reports of Takeover Demise Are Greatly Exaggerated, Wall St. J., June 26, 1987, at 6, col. 1.

7. Arbitrager Ivan Boesky recently was forced to disgorge $\$ 50$ million in illegal insider trading profits. Dennis Levine allegedly earned $\$ 12.6$ million by illegally trading in takeover targets. Stewart \& Hertzberg, Post-Levine Trauma Ends, But Arbitragers Are Hurt by Fallout, Wall. St. J., Oct. 28, 1986, at 1, col. 6. It is likely that continuing investigations will uncover more examples. Systematic abuse of inside information may be a by-product of the change in merger advisory services from a profitable sideline for major Wall Street firms in the 1970's to the mainstay of many of their businesses in the 1980's. Metz, Trading Abuses Run Deep on Wall Street, Wall St. J., Feb. 17, 1987, at 31 , col. 1. Although insider trading has been recognized as illegal since the 1960 's, some commentators believe that it should be permitted and does not harm shareholders. See, e.g., Manne, In Defense of Insider Trading, Harv. Bus. Rev., Nov.-Dec. 1966, at 113.

8. Analysts have proposed various explanations for why takeovers occur at a premium, such as synergistic gains from the combination of two firms and replacement of inefficient managers. See, e.g., Coffee, Regulating the Market for Corporate Control: A Critical Assessment of the Tender Offer's 
of such transactions often depends on maintaining secrecy. An acquirer company incurs considerable "sunk information costs" to identify potential acquisition candidates. These sunk costs include research fees to investment banks, the cost of assembling and holding capital, and the opportunity costs of managers' time. ${ }^{9}$ An insider who knows of an impending tender offer or merger may buy, or tip others to buy, shares of the target before public announcement of the deal. The insider or "tippee" can then sell the shares at a profit when the target share price rises after the takeover information is made public. ${ }^{10}$

Insider trading in target stock prior to the public announcement of a tender offer or merger tends to drive up the stock's price. ${ }^{11}$ This rise in target share price may alert other potential acquirers that the target stock is undervalued, and cause them to make competing bids. Moreover, the price rise may cause the target management to undertake defensive measures. ${ }^{12}$ These developments make the deal more costly to the acquirer and may even abort the takeover.

Suits by acquirers to recoup losses resulting from insider trading would

Role in Corporate Governance, 84 Col.um. L. Rrv. 1145, 1163-75 (1984). Conversely, other commentators have argued that post-merger gains for acquirers are illusory. Compare Langetieg, An Application of a Three-Factor Performance Index to Measure Stockholder Gains from Merger, $6 \mathrm{~J}$. FIN. EcoN. 365, 381 (1978) (mergers lead to normal or slightly superior gains to acquirers) with Malatesta, The Wealth Effect of Merger Activity and the Objective Functions of Merging Firms, 11 J. Fin. ECoN. 155 (1983) (few acquirers gain over long term).

9. Easterbrook \& Fischel, Auctions and Sunk Costs in Tender Offers, 35 STaN. L. REv. 1, 3-7 (1982). See also infra note 23. In addition, the acquirer may suffer a loss on any target stock the acquirer bought before the announcement of the tender offer if the takeover is thwarted. For example, Carl Icahn, after an unsuccessful raid on USX Corporation, found himself stuck with $\$ 600$ million in shares he could sell only at a substantial loss. See When Going Gets Rough, Corporate Raiders Get Scarce, U.S. Nsws \& Wort.p REP., Feb. 23, 1987, at 36.

10. See infra note 11 .

11. See Givoly \& Palmon, Insider Trading and the Exploitation of Inside Information: Some Empirical Fvidence, 58 J. Bus. 69, 69-71 (1985) (insider trading leads to price effects which cause excess return to insider); Keown \& Pinkerton, Merger Announcements and Insider Trading Activity: An Empirical Investigation, 36 J. Fin. 855, 855, 863, 866 (1981); see also Stewart \& Hertzberg, supra note 7 , at 28 , col. 1. Ivan Boesky's trading in a stock based on inside information obtained illegally from Dennis Levine provides a recent example of rapid price rises during a period of insider trading. Boesky started buying shares of Nabisco Brands one week before the announcement of a Nabisco-R.J. Reynolds merger. During the period when Boesky accumulated 377,000 shares, share price rose from $\$ 65$ to $\$ 71$. Boesky made $\$ 4$ million by selling his shares when the merger went through at almost $\$ 83$ a share. Arenson, How Wall Street Bred an Ivan Boeshy, N.Y. Times, Nov. 23, 1986, at F1, col. 3, F8, col. 1; see also infra notes 62-64 and accompanying text.

12. Martin Lipton, the takeover defense law expert, recommends that companies implement a stock watch program to detect accumulations and, where there are particular potential raiders, perform preemptive analysis of the raider from regulatory and financial standpoints. If a company observes unexplained price fluctuations or other signals, Lipton advocates a battery of measures to make the company less vulnerable. $1 \mathrm{M}$. Lipron \& E. Strinbfrger, TAkeovers \& Freizeouts $\$ 6.1$, at $264,293-96$ (1978). When a company becomes a takeover target, various defensive options are open to it, including characterizing the offer as inadequate and filing suits against the raider for violations of the securities laws. Id. at 296-325; see also 13A B. Fox \& E. Fox, Business OrganiZATIONS: CoRporatt: Acouistrtons AND MER(iers § 27.07[1] (1987); see, e.g., Unocal Corp. v. Mesa Petroleum Co., 493 ^.2d 946 (Del. 1985) (defensive tactics upheld under business judgment rule if they are reasonable in comparison to threat posed; selective self-tender offer excluding acquirer approved). 
serve several important purposes. ${ }^{13}$ First, while civil suits by the Securities and Exchange Commission (SEC) and criminal prosecutions provide deterrence by fines, disgorgement, and imprisonment, such suits do not compensate the damaged acquirer. ${ }^{14} \mathrm{~A}$ private suit by an acquirer would serve the goal of providing the acquirer with a legal remedy for its often substantial economic loss.

Second, private enforcement is an effective supplement to SEC actions. ${ }^{15}$ The SEC, with its limited resources, is incapable of pursuing the increasing number of insider trading cases. ${ }^{16}$ If an injured acquirer can bear the costs and share in the benefits of enforcement against inside traders, more detection and deterrence will result, ${ }^{17}$ providing incentives for

13. Recently, several such suits have been brought. See infra notes $38-39$. One might ask why, if suits by acquirers serve beneficial purposes and can be based on common law breach of contract principles, acquirers have not brought these suits before. First, in recent years the government has pursued successfully a greater number of insider trading cases involving very large sums, contributing to the development of the federal securities law on insider trading as well as sometimes providing judgments that can be used collaterally by private litigants against inside traders. See Parklane Hosiery Co. v. Shore, 439 U.S. 322 (1979) (permitting use of offensive collateral estoppel against defendant found in previous suit by SEC to have violated securities laws). Second, attitudes of corporations toward this type of litigation may only now be changing. In the past, companies viewed the substantial legal fees and slim chances of return from suing other companies as a losing proposition. Recently, however, the huge sums of money at stake for acquirers and the development of the law of insider trading (the "misappropriation" theory in particular, see infra note 29 and accompanying text), may have made companies more optimistic about recovery and more willing to risk the costs of litigation. See Power, Insider Trading: Must Employers Pay Damages?, Wall St. J., Sept. 8, 1986, at 29, col. 2. One lawyer involved in the Anheuser-Busch suit, see infra note 38 , has observed that the $\$ 50$ million in illegal profits disgorged by Ivan Boesky may be "only a drop in the bucket when it comes to the damages suffered by a company that made a large acquisition at an inflated price." Lewin, Employer Role in Insider Suits, N. Y. Times, Nov. 18, 1986, at D2, col. 1.

14. Certain injured parties (shareholders who can prove they were harmed) are compensated out of funds of disgorged profits set up and distributed by the SEC. One such fund was set up by the court as part of the final order settling the SEC suit against Kidder, Peabody; the court ordered that a "Disgongement Fund" be set up to compensate plaintiffs with valid claims. SEC v. Kidder, Peabody \& Co., No. 87-3869(RO), slip op. at 10-11 (S.D.N.Y. 1987) (final judgment of permanent injunction).

15. The Supreme Court has "emphasized that implied private actions provide 'a most effective weapon in the enforcement' of the securities laws and are a 'necessary supplement to Commission action.'" Bateman Eichler, Hill Richards, Inc. v. Berner, 472 U.S. 299, 310 (1985) (quoting J.I. Case Co. v. Borak, 377 U.S. 426, 432 (1964)). In addition, Congress has endorsed private enforcement as essential to the Commission's role:

With a relatively small staff charged with administrative responsibility for policing potentially

unlawful securities-related activities, the Commission cannot be expected to bring actions

against even a large portion of those engaged in ... activities that are prohibited by federal

law.... [P]rivate lawsuits serve as an added deterrent to conduct made unlawful by Congress,

without the necessity of government involvement.

H.R. Rr.p. No. 1341, 96th Cong., 2d Sess. 28 (1980); see also Dooley, Enforcement of Insider Trading Restrictions, 66 VA. L. Rr.v. 1, 15 (1980).

16. The number of insider trading cases brought by the SEC more than doubled between 1984 and 1986, and "many fear the S.E.C. may be over its head in dealing with the sheer volume of cases it is uncovering." Nash, Suddenly a Sleepy S.E.C. Is Wide Awake, N.Y. Times, Nov. 23, 1986, at E5, col. 1 .

17. Although some may contend that stricter internal monitoring will disrupt business, the evidence indicates that this will not occur. In the wake of recent scandals, some observers foresee investment houses imposing "draconian regulations" to control the number of people who have access to confidential information. See Why Wall Street Is Rife with Crime, N.Y. Times, Feb. 15, 1987, at F3, col. 1. Firms realize that they must set up more effective controls, perhaps including awareness programs, and will be able to do so at a reasonable cost. See id.; Dingell, First Set Higher Ethical 
enforcement of higher ethical standards at intermediary firms. ${ }^{18}$ Disgorgement of profits by an employee does not place pressure on employers to implement standards that prevent information theft. ${ }^{19}$ The threat of liability for an uninsured loss ${ }^{20}$ will encourage investment banks, law firms and other intermediaries to improve internal controls and screen and monitor their employees more carefully. ${ }^{21}$

Standards, N.Y. Times, Mar. 8, 1987, at 2, col. 2. Recent insider trading scandals have already prompted renewed concern at many businesses. See, e.g., Insider Trading Scandal Prompts Renewed Warnings at Some Concerns, Wall St. J., Dec. 9, 1986, at 1, col. 5 (Lotus Development Co. sends strongly worded letters to employees warning against trading on inside information; Raytheon Co. produces new videotape and booklet on ethical questions, including handling of confidential information, to supplement bi-annual warnings from legal department). Other precautions might include requiring an employee to get permission from his superior before discussing a takeover deal with someone in another department of the firm, barring employees from personal investment in the stock market or, for investment banks, physically isolating stock arbitrage departments.

Moreover, in the recent settlement by consent agreement of the SEC's charges against Kidder, Peabody, an investment bank, Kidder agreed to engage outside consultants to strengthen its review and compliance procedures, including measures to prevent and detect insider trading. In re Kidder, Peabody \& Co., Adm. Proc. No. 3-6855, slip op. at 2-4 (SEC June 4, 1987) (SEC order).

18. In an analogous context, accountants responded to expanded legal liability by improving their standards and techniques. See Mess, Accountants and the Common Law: Liability to Third Parties, 52 Notrk: DAMt: LAw. 838, 855-57 (1977) (discussing beneficial effect of increased liability of accountants). Moreover, placing liability of this magnitude on financial and advisory service firms is not unprecedented. For example, liability has been imposed on firms for misrepresentation and lack of due diligence in connection with securities offerings in order to strengthen industry performance standards. See, e.g., Escolt v. Barchris Constr. Corp., 283 F. Supp. 643 (S.D.N.Y. 1968) (defendant lawyers, underwriter, and accountants who prepared registration statement for sale of debentures failed to meet required standard of due diligence to avoid liability under section 11 of the Securities Act of 1933 (codified as amended at 15 U.S.C. $§ 77(\mathrm{k})(1982)$ ).

19. Employers set standards for internal monitoring and determine the seriousness with which employees will regard the internal rules. See supra note 17.

20. See Shoultz, Also in the News: Shearson's Liability, Am. BANkeR, Aug. 25, 1986, at 13 (insurance and legal sources say insurance contract of investment bank does not cover liability for suit by acquirer client against investment bank for insider trading of employee).

21. On the other hand, some argue that there may be little more that employers can do to deter insider trading. See Insider Trading Dilemma, 21 MrRgers \& Acquisitions, July/Aug. 1986, at 7. When hiring employees, firms find it hard to predict who might trade on inside information. But see Bean, More Firms Use "Attitude Tests" to Keep Thieves Off the Payroll, Wall St. J., Feb. 27, 1987, at 41 , col. 3 (written tests can predict how likely prospective employee is to be dishonest and steal from employer). The motivation for insider trading in many cases appears to be the conclusion that, after weighing the potential benefit against the probability of detection, chances of being caught are very small. See Vise, Levine Case Insider Gets Prison Term, Wash. Post, Nov. 7, 1986, at F2, col. 3 (statement by United States Attorney Rudolph Giuliani that people in investment banking and securities business "balance risk of getting caught and consequences of apprehension versus the potential for easy money"). $\Lambda \mathrm{n}$ effective method of increasing deterrence is to improve and publicize detection procedures used mainly by the SEC and the securities exchanges. In late 1986, the chairman of the SEC requested a budget increase to improve the SEC's computerized filing system for corporate reports and to bolster the SEC's enforcement staff. Ingersoll, Bigger SEC Budget, Clearer Definition of Insider Trading Backed by Senators, Wall St. J., Feb. 25, 1987, at 5, col. 1; Ingersoll \& Swartz, Shad Is Seeking Biggest SEC Budget Rise in 50 Years to Bolster Enforcement Effort, Wall St. J., Dec. 8, 1986, at 5, col. 1. Nonetheless, firms can play a role in raising the probability of detection through internal procedures, such as strictly monitoring the access of employees to sensitive information and limiting access to those working on a deal, and through cooperation with agencies investigating abnormal trading patterns. Some firms now have policies requiring employees to disclose all trading activity or even to refrain from owning any securities. See supra note 17. In fact, firms which qualify as broker/dealers under the Securities $A c t$ are required by regulation and by the securities exchanges to monitor the trading activities of their employees. See, e.g., 17 C.F.R. $\$ 240.17 a-3(a)(7)$ (1986). 
Third, acquirers will be more likely to incur sunk $\operatorname{costs}^{22}$ to obtain information leading to value-increasing business combinations if they believe there is a significant chance that they will be made whole should their information be misused. ${ }^{23}$ Commentators argue that a fluid market for corporate control, including the threat of cash tender offers, is important in creating incentives for management to maximize shareholder wealth, because the possibility of a takeover serves as a check on management. ${ }^{24}$ Thus, compensating acquirers fosters efficiency by preserving incentives for value-increasing transactions which maintain fluidity in the market for corporate control.

\section{B. Possible Causes of Action by an Acquirer}

Despite the growing sophistication of insider trading law, neither federal securities law nor common law tort actions can offer an injured acquirer adequate recovery. First, while the SEC and an injured purchaser or seller of a security may sue an inside trader under SEC Rules $10 \mathrm{~b}-5^{25}$ and $14 \mathrm{e}-3,{ }^{28}$ which prohibit certain purchases or sales of securities while a trader is in possession of material, nonpublic information, ${ }^{27}$ an acquirer probably cannot sue under either of the two securities law approaches to insider trading used by the courts. Under traditional Rule $10 \mathrm{~b}-5$ analysis,

22. See supra text accompanying note 9.

23. See Fischel, Efficient Capital Market Theory, the Market for Corporate Control, and the Regulation of Cash Tender Offers, 57 Trx. L. Rrv. 1, 1 (1978). The incentive to undertake research costs is the anticipated gain from the increase in value of the offeror's equity investment after seizing control. Id. at 4-5. When the law protects the ability of owners of privately produced information (acquirers) to turn the information into profit, the production of new information will be encouraged. Recognizing a property right in privately produced information will increase incentives to produce this information. Id. at 27.

There is a distinction between the detriment to acquirers caused by insider trading, on one hand, and that caused by permissible defensive tactics, on the other. The issue of whether acquirers should be able to protect their information before a public bid is different from the debate over whether postbid delays should be encouraged. Post-bid delays may deter searching, but they have the potentially countervailing positive effect of promoting auctions. See, e.g., Bebchuk, The Case for Facilitating Competing Tender Offers, 95 HARv. L. Ryv. 1028 (1982). In contrast, pre-bid leaks caused by insider trading entail the same deterrent to searching as post-bid delays without a corresponding benefit. In other words, the pre-bid price rise may tip off other acquirers and begin an auction, but it primarily benefits the dishonest inside traders. But see Manne, supra note ?.

24. Fischel, supra note 23 , at 1 .

25. Rule $10 \mathrm{~b}-5$ states that it shall be unlawful for any person:

(a) To employ any device, scheme, or artifice to defraud,

(b) To make any untrue statement of a material fact or to omit to state a material fact . . . ,

(c) To engage in any act, practice, or course of business which operates or would operate as a

fraud or deceit upon any person,

in connection with the purchase or sale of any security.

17 C.F.R. $\S 240.10 \mathrm{~b}-5$ (1986).

26. 17 C.F.R. $\$ 240.14 \mathrm{e}-3$ (1986). Section 14(e) of the Securities Exchange $\Lambda$ ct of 1934 (codified as amended at 15 U.S.C. $\$ 78 \mathrm{n}(1982)$ ) prohibits fraud in connection with a tender offer.

27. For a classic example of an insider trading case, see SEC v. Texas Gulf Sulfur Co., 401 F.2d 833 (2d Cir.), cert. denied, 394 U.S. 976 (1968). In Texas Gulf Sulfur, corporate employee insiders traded on the basis of material, nonpublic information regarding mineral discoveries by their employer. A suit by an acquirer against an intermediary is different because the valuable information concerns developments affecting the stock price of another company, the target. 
recovery is predicated upon a fiduciary relationship based on trust and confidence between the inside trader and the selling shareholder. An acquirer, under such analysis, would have no cause of action because it is not owed such a duty; only the selling shareholders may sue, provided a duty is owed to them. An intermediary hired by an acquirer would not owe a duty to the selling shareholders. ${ }^{28}$ Under the newer and uncertain "misappropriation" theory ${ }^{28}$ endorsed by the Second Circuit, client acquirers lack standing to assert a claim under Rule 10b-5. The misappropriation theory posits that because information is known to be of value and disclosure is, or should be, known to be damaging, the wrongful conversion of information to one's own use by buying or tipping others is actionable under Rule $10 \mathrm{~b}-5$. In government enforcement actions, courts have held that use of confidential information by an employee of an intermediary violates a duty owed to their client. ${ }^{30}$ For a private plaintiff to have standing under Rule $10 \mathrm{~b}-5$, however, he must be a purchaser or seller of securities who was defrauded at the time the insider trading took place. ${ }^{31}$ An acquirer could not meet this test with regard to the bulk of securities purchased in an acquisition. ${ }^{32}$

28. Dirks v. SEC, 463 U.S. 646, 655 (1982); Chiarella v. United States, 445 U.S. 222 (1980) (tinancial printer engaged by acquirer who traded on confidential client information not liable for violation of Rule $10 \mathrm{~b}-5$ because printer owed no duty to target shareholders with whom he traded). If, however, officers or directors of the acquirer were to trade or tip on the basis of secret takeover information, they would violate Rule 10b-5. See supra note 27.

29. The Supreme Court recently decided Carpenter v. United States, No. 86-422 (U.S. Nov. 16, 1987) (LEXIS, Genfed library, US file), a case involving former Wall Street Journal reporter Foster Winans, who was convicted of violating Rule $10 \mathrm{~b}-5$ by trading on the basis of confidential publication schedules he "misappropriated" from his employer. The Court affirmed the mail and wire fraud convictions by 8 to 0 , but deadlocked by 4 to 4 on the securities fraud issue concerning the misappropriation theory. The lower court's holding on the securities fraud issue remains intact, but the Supreme Court opinion on this issue lacks precedential value.

$\Lambda$ bill on insider trading has been introduced in the U.S. Senate that would codify in large part the misappropriation thenry. The bill would provide for liability of intermediaries if the intermediary knows, or is reckless in not knowing, that either the tipping of the information or trading on the tipped information is wrongful. In determining liability, it will be relevant to what extent the employer has taken reasonable steps to prevent and detect the proscribed conduct. The Insider Trading Proscriptions Act of 1987, S. 1380, 100th Cong., 1st Sess., 133 Conc. Rfc.. 8248-49, 8251 (1987).

30. See, e.g. SEC. v. Materia, 745 F.2d 197, 203 (2d Cir. 1984) (misappropriation of confidential information regarding tender offers by employee of financial printer, and subsequent trading on such information, breached duty owed to employer's client and violated Rule 10b-5), cert. denied, 471 U.S. 1053 (1985); United States v. Newman, 664 F.2d 12, 17 (2d Cir. 1981) (securities trader who fraudulently misappropriated confidential information for personal gain held criminally liable for breaching duty owed to his employer's clients "whose takeover plans were keyed to target company stock prices fixed by market forces, not artificially inflated through purchases by purloiners of confidential information"), cert. denied, 464 U.S. 863 (1983).

31. Blue Chip Stamps v. Manor Drug Stores, 421 U.S. 723 (1975); Birnbaum v. Newport Steel Corp., 193 F.2d 461, 464 (2d Cir. 1952). The purchaser-seller requirement is not applicable in a government law enforcement action. See Blue Chip, 421 U.S. at 751 n.14 (citing SEC v. National Sec, Inc., 393 U.S. 453,467 n.9 (1969)); see also United States v. Naftalin, 441 U.S. 768,774 n.6 (1979).

32. Piper v. Chris-Craft Indus., 430 U.S. 1 (1977) (tender offeror does not have standing to sue in private damage action under Rule 14-e; purpose of tender offer rules is to protect shareholders of tendered company, not to protect tender offeror). Thus, the class of injured acquirers is not currently protected. The only argument an acquirer could make is that it should be considered an injured purchaser because it later bought a block of target stock after making an offer and was defrauded (i.e., 
Alternatively, a client company might bring a tort action against an inside trader or tipper for common law conversion ${ }^{33}$ or breach of duty of confidentiality owed to an employer. ${ }^{\text {34 }}$ Such a suit for "theft" of information might result in damages such as disgorgement of that employee's profits to the client. ${ }^{35}$ The personal gains of an insider, however, are small compared to the loss suffered by acquirers from a higher target share price caused by the leak of information to the market. ${ }^{36}$ Because most individuals' pockets are relatively shallow, such suits would be worthwhile only where a plaintiff company can collect on the basis of the secondary liability of the intermediary firm employing the insider. Proving the vicarious liability of an employer using a respondeat superior or negligent supervision theory would be difficult in most cases. ${ }^{37}$

paid an artificially high price) in connection with that purchase. Blue Chip and Piper v. Chris-Craft do not completely foreclose the possibility of an action by an acquirer under 10b-5 against an inside trader intermediary. While the unsuccessful plaintiffs in Blue Chip claimed that they were misled into passing up an opportunity to purchase securities at a bargain price, a plaintiff acquirer here will actually have purchased the security affected by the fraudulent conduct.

The standing of an acquirer against an inside trader could be distinguished from that of the plaintiff in Piper v. Chris-Craft. Although Chris-Craft alleged that Bangor fraudulently manipulated the price of Piper shares that Chris-Craft later bought, Chris-Craft never alleged that the price it had paid for the Piper shares was affected by Bangor's manipulation. The Court implied that the result might be different in the case of a plaintiff who linked a defendant's fraud with the plaintiffs purchase at a higher price. Piper, 430 U.S. at 45 . A plaintiff acquirer in a suit against an intermediary inside trader makes just that allegation-that insider trading inflated the premium paid to obtain a target. The extent of recovery under Rule 10b-5 may be strictly restricted, however, because some courts have imposed a "contemporaneous trading" requirement whereby inside traders are liable only to those who trade at the same time as the insider does. See, e.g., Wilson v. Comtech Telecommunications Corp., 648 F.2d 88 (2d Cir. 1981). Since an inside trader often has sold his shares before a tender offer has been made and an acquirer buys, this requirement is often a bar to an acquirer suit. Even when the requirement does not act as a complete bar to recovery, it may impose significant limitations on the amount a plaintiff can recover; an acquirer may be able to recover damages as a defrauded purchaser only for stock the acquirer purchased (before commencing a tender offer) during the period when an insider had bought based on the inside information. See Shapiro v. Merrill Lynch, Pierce, Fenner \& Smith, Inc., 495 F.2d 228, 237 (2d Cir. 1974) (insider owes duty not only to purchasers of his actual shares, but to all persons who purchased stock during same period in open market).

33. Conversion is the unauthorized use of information with which an employee was entrusted in such a manner as to constitute a material breach of the employee's authority. See $18 \mathrm{AM}$. JUR. 2D Conversion $\$ \S 1,7,9$ (1985).

34. The tort of breach of a duty of confidentiality to an employer is well established. See, e.g., Franke v. Wiltschek, 209 F.2d 493, 495 (2d Cir. 1953) (Clark, J.); see also 2 RestA.rement (SECOND) OF AGENCY $\S 395$ (1958); if. infra note 45 and accompanying text.

35. In many cases, however, litigation costs would outweigh the value of disgorgement.

36. Even if a client company can prove damages beyond the insider's gain, most individuals will be judgment-proof against such large sums.

37. Both of these theories depend on establishing a close nexus between an employee's duties at the employer firm and her illegal behavior. Under respondeal superior, an employee's act must be within the scope of her employment-a difficult standard to meet in cases of well-hidden inside trading or tipping. A plaintiff could argue, however, that inside traders obtained confidential information through the use of firm facilities. Cf. SEC v. Management Dynamics, Inc., 515 F.2d 801, 812-13 (2d Cir. 1976) (corporation liable through respondeal superior for actions of executive who used firm facilities in creating misleading appearance of activity in stock). Negligent supervision is implicated because inside trading or tipping often is done not by an employee working on a particular transaction, which would be too obvious, but by another employee in the office who learns of the deal. In such cases, a plaintiff would contend that by not barring employees' access to information about transactions in which they are not involved, a firm may be negligent in its supervisory function. See supra 
The obstacles presented by claims under the federal securities laws and tort law make breach of contract an attractive alternative cause of action under which acquirers can recover. Injured firms have only recently begun to adopt this approach. By the end of 1986, three suits, alleging hundreds of millions of dollars in damages, had been filed by acquirers charging insider trading by intermediaries. ${ }^{38}$ In early 1987 , several additional acquirer suits were brought in the aftermath of the exposure of the largest insider trading scandals in history. ${ }^{39}$

\section{LIABILITY OF INTERMEDIARIES}

\section{A. Liability of Investment Bankers-A Contract Theory}

The contractual relationship between an acquirer and an intermediary should provide the basis for imposing liability when an employee-agent of the intermediary inside trades on the acquirer's information. Typically, when an acquirer hires an investment bank, ${ }^{40}$ the parties enter into an agreement specifying the obligations of the investment bank ${ }^{\mathbf{4 1}}$ and often

note 17.

38. Acquirer suits present an issue of first impression in the courts. Within the last year, two client firms have filed actions against employees and their investment bank employers for the extra amount they were forced to pay for target companies after insider trading pushed up share prices. See Litton Indus. v. Lehman Brothers Kuhn Loeb, Inc., No. 86-6447 (S.D.N.Y, filed Aug. 19, 1986); Anheuser-Busch Cos. v. Thayer, No. CA3-85-0794-R (N.D. Tex. filed Apr. 26, 1985). Acquirers contend that investment banks should be responsible for the misuse of client information by their employees and have asserted contract, tort and federal securities claims. Lengthy discovery continues in Anheuser-Busch, which is scheduled for trial in 1988. An answer has been filed in the Litton case and discovery has begun. In addition, FMC Corp. filed suit against its investment bank, Goldman, Sachs, an alleged tipper. David Brown, alleged tippees, and inside traders Dennis Levine and Ivan Boesky charging that Boesky's insider trading added \$225 million to the cost of FMC's recapitalization plan. FMC Charges Boesky's Trading Raised Costs of Recapitalization \$225 Million, Wall St. J., Dec. 19, 1986, at 8, col. 3; see also Boeshy the Terrible, Wall St. J., Nov. 18, 1986, at 32, col. 1. FMC alleged breach of contract by Goldman, Sachs, its investment bank, and numerous federal and state law claims. Complaint at 44, FMC Corp. v. Boesky, No. 86-9879 (N.D. Ill. filed Dec. 18, 1986). $\Lambda$ district court judge dismissed preliminarily part of the suit on grounds that FMC had not demonstrated that Boesky and others had harmed the company by their actions, and, thus, Article III standing was lacking because of lack of injury. The court noted that FMC may pursue its state law claims elsewhere and may "seek recovery ... on the theory of breach of contract." FMC v. Boesky, No. 86C9879, slip op. at 20 (N.D. III. Apr. 16, 1987). FMC plans to appeal the adverse ruling and continue to seek damages for the additional costs it paid during its financial restructuring. FMC Plans to Appeal Dismissal of Lawsuit Involving Boeshy, Wall St. J., Apr. 17, 1987, at 7, col. 3.

39. Recently two suits based on similar principles of breach of fiduciary and contractual duties were filed in connection with the 1984 takeover of Carnation by Nestle. Investors allege that Martin Siegel, an employee of Carnation's financial advisor, the investment bank Kidder, Peabody, leaked information to trader Ivan Boesky. Carnation shareholders who sold while the alleged insider trading was taking place are claiming more than $\$ 60$ million in damages from Boesky, Siegel, and Kidder, Peabody. Carnation Investors Are Seeking Damages from Boesky Scandal, Wall St. J., Feb. 24, 1987 , at 5 , col. 1 .

40. Acquirers hire investment banks to identify acquisition candidates, negotiate transactions, and prepare valuations of companies under consideration. See generally P. FERRIS, THE MASTER BANKERS (1984) (describing investment banking).

41. These agreements, called "engagement letters," set out the specific services the investment bankers will provide, the fees they will be paid (usually with a contingency bonus for a percentage of the value of the deal if successful), reimbursement for expenses, and the terms of any indemnification or release. 2 M. Lipron \& E. Strinberger, Takeovers \& Freezeouts C-15-37 (4th ed. 1986). 
including a provision that any advice and information generated by the investment bank at the request of the client will be given to and used solely by the client. ${ }^{42}$ Such a provision demonstrates that the client has bargained for exclusive use of information relating to potential and actual targets and that misuse of the information by inside trading or tipping by an employee of the bank is a breach of the contract, enforceable under state law. In the wake of recent scandals, clients are more likely to insist on explicit confidentiality provisions. ${ }^{\text {ts }}$

Even if an engagement letter does not contain precise terms spelling out the duty of the investment bank regarding confidentiality, these terms can be reasonably implied. Confidential information is a property right for which the client is paying, and use of the information by others clearly reduces its value. A small amount of insider trading and tipping can disseminate information widely in the market, eroding the opportunity for gain which the acquirer has identified.44 The client reasonably expects that the investment bank has been hired to identify and facilitate transactions for the benefit of the client alone. The only compensation to the investment bank and its employees is that specified in the agreement and not insider trading profits. The relationship of the parties is such that confidentiality is an essential and expected term of their working relationship. A breach of confidentiality in this context should give rise to contractual liability. ${ }^{45}$

In addition, this argument is supported by the common law, which provides that an agent has a duty not to use the principal's resources, includ-

42. A client secks to lower the risk of investment bank employees using such knowledge for their own benefit. For example, in the engagement letter signed when Litton hired the investment bank, Lehman Brothers, Lehman agreed that it and all its employees would strictly maintain the confidentiality of any information collected in connection with Litton's plans to acquire Itek. Second Amended Complaint at 10, Litton Indus. v. Lehman Brothers Kuhn Loeb, Inc., No. 86-6447 (S.D.N.Y. filed Aug. 19, 1986). Another engagement letter, this time between Goldman, Sachs and a client, stipulated that:

Such opinion and any advice, written or oral, provided by Goldman, Sachs \& Co. pursuant to this letter will be solely for the information and assistance of the Company in connection with its consideration of a transaction of the type referred to [above] and are not to be used, circulated, quoted or otherwise referred to for any other purpose.

Letter from Goldman, Sachs \& Co. to Planning Research Corp. (Oct. 24, 1986) (on file with author).

43. Colin Blaydon, the dean of the Amos Tuck School at Dartmouth, has gone so far as to say that "[t]oday nobody in his right mind would show his investment banker sensitive information without assurances or a written agreement about disclosure." Byrne, Corporate Clients Feel Seduced and Abandoned, Bus. WK., Mar. 2, 1987, at 34, col. 1.

44. See Gilson \& Kraakman, The Mechanisms of Market Efficiency, 70 VA. L. REv. 549, 570 (1984); see also Easterbrook, Insider Trading, Secret Agents, Evidentiary Privileges, and the Production of Information, 1981 Sup. Cr. Rev. 309, 331 (disclosure of information by insider trading reduces value of information to its rightful owner). Some commentators suggest that the Supreme Court has moved in the direction of a "property rights" focus in its application of the insider trading laws. See Macey, From Fairness to Contract: The New Direction of the Rules Against Insider Trading, 13 Horstra L. REv. 9, 12 (1984).

45. Intention to make a promise may be manifested from the course of dealing between the parties. See Ristatriminr (Stconn) of Contracts \$ 4 comment a (1981) (implied contracts have same legal effect as express ones). 
ing information, for personal gain. ${ }^{48}$ Courts should interpret agreements between investment banks and clients to mean that an intermediary has assumed an explicit or implied contractual duty to take prudent precautions to prevent its employees from trading or tipping on the basis of client information. Courts should look to prevailing practices within an industry to determine what constitute reasonably prudent internal procedures. ${ }^{47}$ Any other interpretation of the contract would not adequately protect clients' property interests ${ }^{\mathbf{8}}$ in their information or create sufficient incentives for employers to monitor the flow of information.

Liability for breach of confidentiality will be an effective sanction only if investment banks are not contractually released from liability to their clients by a covenant not to sue. The extent to which an investment banker is indemnified for damages and legal fees arising from a client/ bank relationship is an important point of negotiation in the engagement letter. ${ }^{19}$ In some cases, the agreement does not provide for release from liability if the investment banker is "negligent";so in such cases, there

46. See, e.g., RESIATEMENT (SECOND) OF AGENCY $\$ 395$ comment a (1958) ("an agent who is told by the principal of his plans ... is not privileged to use such information at his principal's expense"). The case of an acquirer suing its investment bank can be analogized to the situation in which a collector makes an agreement with an agent that the collector will pay the agent a certain amount to scour pawn shops in search of watches which are for sale at prices less than they are worth. If the agent were to buy the watch himself or tell the seller to raise its price before the collector has a chance to buy, the agent would be violating his contractual duty to the employer/principal. Similarly, when an insider trades or tips, he alerts the target (the "watch seller") of its undervalued status and deprives the client of potential gain. This situation may also be compared to the case in which an entrepreneur entrusts a trade secret in confidence to a manufacturer who then uses the secret for personal gain, outside the terms of the agreement reached with the entrepreneur. See, e.g., Schreyer v. Casco Prod. Corp., 190 F.2d 921, 924 (2d Cir. 1951), cert. denied, 432 U.S. 913 (1952).

47. See supra note 17 ; infra note 51 . Obviously, courts could not unduly burden intermediaries by holding them to a standard close to strict liability.

48. See supra note 44.

49. See Note, Investment Bankers' Fairness Opinions in Corporate Control Transactions, 96 YA1.E. L.J. 119, 140 n.122 (1986). A clearer liability standard for intermediary firms will have lasting effect in that the market for intermediary services will constrain the extent to which parties can negotiate away liability. $\Lambda$ client will not release all its rights against an intermediary because it will want some assurance of the integrity of the firm it engages and will be willing to pay some increased cost to obtain this assurance. Clients greatly value the ability of intermediaries to maintain confidentiality. Cf. Stevenson, A Broker Who Went Too Far, N.Y. Times, Mar. 20, 1987, at 33, col. 3 (Jefferies \& Co., a brokerage concern used by corporate acquirers, appears to have been popular with big investors because it afforded its clients greater confidentiality than that available at other brokerage houses. For example, clients were identified internally only by code numbers and letters to minimize the chance of leaks.). Because clients will be attracted to firms with high internal standards, the intermediary will still want to assume as much of the risk as it can control through monitoring mechanisms. Thus, in future engagement agreements, it will continue to be efficient to allocate the risk of loss from intermediary employee insider trading to the intermediary, who is best able to take additional precautions.

50. The following is an example of a release with convenant not to sue contained in an indemnity provision in an engagement letter. This provision does not release the investment bank for actions arising from its bad faith or negligence:

We also agree that neither you, nor any of your affiliates, nor any officer, director, employee or agent of you ... shall have any liability to us for or in connection with such engagement except for any such liability for losses, claims, damages, liabilities or expenses . . . that result primarily from your bad faith or negligence.

2 M. Lipion \& E. Strinberger, supta note 41 , at C-18. 
would be no obstacle to a client's suing for breach of contract because its bank insufficiently monitored the use of confidential information. ${ }^{\text {sI }}$

In other cases, a bank may be released by a covenant not to sue except for claims arising from the "gross negligence" or "bad faith" of the bank. ${ }^{52}$ In such situations, a bifurcated standard may be useful in identifying "gross" rather than "ordinary" negligence on the part of a bank. For example, if a partner or managing director of a bank ${ }^{53}$ trades or tips on the basis of confidential information, it is reasonable to rely on principles of partnership or enterprise liability and classify this behavior as gross negligence by a firm. ${ }^{\text {s4 }}$ A professional group should be responsible for reasonable knowledge of the integrity of its members. If, however, a lower level employee, such as a file clerk or analyst, trades or tips, it would be more difficult to hold a bank to a duty of strict supervision. Depending on the monitoring devices used, however, a firm could be implicated in the illegal activities of non-managerial employees. A difficulty with this approach would be to determine within the middle levels of

51. Some financial firms have less stringent procedures, while others maintain extensive systems to keep all important information within the group that is working on a deal. For example, at the mergers and acquisitions department of E.F. Hutton, code names are used in all communications for details such as the project, client, and other companies involved. Any request for information from the firm's research department or outside sources must be cleared by the "leader" of the team working on the deal, and team members are instructed not to discuss any projects or travel plans within "hearing range" of people not on the team or in any public place. Insider Trading Dilemma, 21 MERGERS \& Acouisrrions, July/Aug. 1986, at 7-8. If a firm did not engage in procedures similar to those of Hutton, one could argue that the firm was negligeint in its supervisory function. See supra note 17 (precautions firms can take).

Recently, law firms have become more concerned about attorneys and other employees investing or trading in client-related stock. One author advocates providing clear written guidelines for investments, requiring all employees to sign an agreement that they understand and agree to abide by the policy, and holding periodic meetings to explain the guidelines and emphasize the consequences of a violation. Judge, Getting Tough on Attorney Investing, AM. LAw., April 1987, at 10.

52. The following is an example of a release with covenant not to sue contained in an indemnity provision in an engagement letter. This provision releases the investment bank for all actions except those arising from gross negligence or bad faith ("willful misfeasance"):

The Company agrees to indemnify and hold Investment Banker harmless against any and all losses, claims, damages, liabilities, or expenses ... to which Investment Banker may become subject arising from or in connection with the services which are the subject of this letter ... provided, however, that the Company shall not be obligated under the foregoing imdemnity [sic] agreement in respect of (i) any loss . . . to the extent that a court having jurisdiction shall have determined by a final judgment that such loss ... resulted from the willful misfeasance or gross negligence of Investment Banker ....

2 M. LiPTON \& E. STrinBERGER, supra note 41, at C-22. Indemnification for intentional or reckless action would be unenforceable on grounds of public policy. Rrstatrment (SECOND) OF CONTRACTS $\S 195.1$ (1981).

53. For example, Dennis Levine was a managing director at Drexel Burnham Lambert and Martin Siegel was a partner at Kidder, Peabody. See supra note 1.

54. In a partnership, any partner may be held liable in damages for the professional negligence of any co-partner. 60 AM. JUR. 2D Partnership $\$ 166$ (1972). In this context, where an investment bank undertook to maintain confidentiality of information, the misuse of client information for personal gain clearly constitutes professional negligence. In addition, with regard to conversion, the Uniform Partnership Act provides that a partnership is bound to make good where the partnership in the course of its business receives property (i.e., in this case, the confidential information) of a third person (the client) and the property so received is misapplied by any partner while it is in the custody of the partnership. UNIF. PAR'TnERshIP ACT $\$ 14$ (1969). 
managerial personnel precisely what constitutes gross negligence on the part of the employer.

\section{B. Liability of Other Intermediaries}

In addition to investment bankers, lawyers and accountants owe their clients a duty to maintain confidentiality and prevent misuse of client information. ${ }^{\mathrm{Bs}}$ Lawyers who use client information for personal gain violate their ethical duty. ${ }^{\mathrm{Bs}}$ Moreover, any attempt to indemnify lawyers (and probably accountants) would fail as a violation of professional ethical standards and perhaps as an agreement against public policy. ${ }^{57}$ Thus, a client firm can rely on the breach of duty of confidentiality or professional negligence theory against lawyers and accountants ${ }^{\mathrm{s8}}$ - a corollary of the contract theory used against investment bankers.

\section{Causition and Proof and Galculation of Damages}

The enormity of the potential liability of intermediaries whose employees trade on the basis of clients' confidential acquisition plans makes civil

55. Other intermediaries who become privy to a deal before it is publicly announced, such as printers, public relations firms, proxy solicitors, and banks forming a syndicate to provide financing for the deal also may be held liable to an acquirer for breaching the terms of their engagement by the acquirer, depending on what these terms are. Printers and public relations firms have been sued by the SEC for insider trading on the basis of confidential client information. See supra notes 28 and 30; Walsh, Public Relations Firm Charged with Insider Trading, 42 PUB. REL. J. 10 (1986).

56. The American Bar Association Model Rules of Professional Conduct state: "A lawyer shall not reveal information relating to representation of a client unless the client consents . . except for disclosures that are impliedly authorized in order to carry out the representation." MODEL RuLEs of Professional. Conduc:r Rule 1.6 (1986). Lawyers have been reprimanded for profiting from client confidences. See, e.g., In re Nigohosian, 88 N.J. 308, 442 A.2d 1007, 1010-11 (1982) (lawyer disciplined for surreptitiously purchasing property in which client was interested); see also C. WolfrAM, Modirn Lesial. Erhics \& 6.7 .6 (1986). In addition, Rule 1.15 requires a lawyer to hold in trust, separate from his own property, property of clients that is in a lawyer's possession in connection with a representation, Monkl. Rul.ss of Proftssional. Conducr Rule 1.15 (1986), and to hold the property with the care required of a professional fiduciary. Id. at comment; see, e.g., Bar Ass'n v. Marshall, 269 Md. 583, 307 ^.2d 677 (1973) (lawyer must treat property of client with special care and meet highest standards of accountability); see also C. Wolfram, supra, § 4.8. Thus, a lawyer will be held to a high standard in safeguarding confidential information entrusted to her. $C f$. supra note 1 (lawyers have been charged in recent insider trading scandals). Moreover, a lawyer has certain responsibilities regarding nonlawyer assistants and could be held accountable for the assistant's trading or tipping. Rule 5.3 requires a partner in a law firm to "make reasonable efforts to ensure that the firm has in effect measures giving reasonable assurance that the [nonlawyer assistant's] conduct is compatible with the professional obligations of the lawyer." Model Rules of Professional. ConDucr Rule 5.3 (1986). These efforts include giving such assistants "appropriate instruction and supervision concerning the ethical aspects of their employment, particularly regarding the obligation not to disclose information relating to representation of the client." Id. at comment. Although the Model Rules are not law, they prescribe a standard of conduct below which an attorney would likely be found negligent.

57. See Rrsiatrimkini (Shicond) of Contracts $\S 193$ (1981). Such an agreement could be considered a promise that tends to induce a violation of fiduciary duty, and, thus, unenforceable on grounds of public policy.

58. An accountant is not automatically a fiduciary for his client, but the client may prove that the accounting services and confidential financial advice provided by the accountant gave rise to a fiduciary duty. See Stainton v. Tarantino, 637 F. Supp. 1051 (E.D. Pa. 1986); see also Chambers v. Kaleidoscope, Inc., 650 F. Supp. 359 (N.D. Ga. 1986). 
damage suits by acquirers for increased costs of takeovers an alarming prospect to Wall Street employers. ${ }^{59}$ While the common law provides a cause of action for breach of contract or fiduciary duty for acquirers, the issues relating to causation and damages appear complex and controversial. Nevertheless, innovative solutions can overcome such difficulties.

\section{A. Causation and Proof of the Acquirer's Loss}

For acquirers to prove compensable loss in value with reasonable certainty they must establish two causal links: first, that the insider trading or tipping, in breach of the agreement, caused the target share price to rise; and, second, that the acquirer paid a higher price for the target than it would otherwise have paid because of the increased share price before public announcement. ${ }^{60}$ In proving the first prong, acquirers should assert that insider trading devalues their information by causing a rise in the price of the target's stock in the period before any public announcement of their bid. ${ }^{61}$ Although isolating a single cause is difficult because stock prices respond to many stimuli, ${ }^{62}$ commentators have demonstrated that, despite the large number of variables, a few knowledgeable traders who control a crucial volume of trading activity can rapidly cause a stock price to reflect new information. ${ }^{63}$ Even a single informed trader may cause

59. Litton Industries, for example, in a suit against investment bank Shearson Lehman Brothers, estimates its loss in the takeover of Itek at $\$ 30$ million. Litton Indus. v. Lehman Brothers Kuhn Loeb, Inc., No. 86-6447 (S.D.N.Y. filed Aug. 19, 1986). In another case, FMC has filed suit seeking $\$ 225$ million. FMC Corp. v. Boesky, No. 86C9879, slip op. at 20 (N.D. Ill. Apr. 15, 1987); see supra note 38.

60. Even if an injured acquirer cannot meet the burden of proving its lost profits with sufficient certainty, to the extent that the acquirer relied on the contract in making commitments and spending money, it can recover these costs as damages if the breach frustrates its venture, as it does in this situation. See E.A. FARnsworTh, ConTracts $\$ 12.16$, at 888-89 (1982) (reliance as an alternative measure of damages). Thus, in addition to paying an inflated price for shares purchased when the tender offer or merger takes place, the acquirer must pay more on the open market for shares bought before the transaction is announced. An acquirer may purchase up to $5 \%$ of a target before being required to file a Form 13D with the SEC, stating its intentions. 17 C.F.R. $\$ 240.13 d$ (1979). After filing, the acquirer may continue to purchase shares. Id. In the typical tender offer, an acquirer will acquire a substantial block of stock in the target before commencing the offer, claiming on the Form 13 that it holds these shares for "investment purposes."

61. See supra note 11 and accompanying text.

62. Systematic market forces, see Modigliani \& Pogue, An Introduction to Rish and Return: Concepts and Evidence, 30 Fin. ANAlysts J. 68, 76-77 (2d ed. 1964); R. BREAl.EY \& S. MYers, Principles of Corporate. Finance: 140 (2d ed. 1984), industry specific factors, and speculators (short-swing traders, such as arbitragers, who buy or sell because of recent changes in the price of a security) may cause shifts. Another bidder may have entered the picture as a result of its own research. Insiders of the client or the target may be trading. The target itself, attuned to any fluctuation, may try to deflect suspected maneuvers by defensive tactics which affect stock price. Finally, the relationship between buying, selling and share price is complex. See infra notes 63-64. Factors such as speculation in the media about rumored takeovers, acquisition of "foothold positions" in the target company's stock by the bidder and whether the offer is a friendly one may help explain increases in target stock prices before takeover bids are announced. Factors Other Than Insider Trading Can Boost Stock Price Before a Bid, SEC Says, Wall St. J., Mar. 11, 1987, at 4, col. 5.

63. See, e.g., Givoly \& Palmon, supra note 11 , at 69, 86 (major part of observed abnormal performance of insiders likely to be due to price changes arising from information revealed through insider trades themselves); R. BREALEY, AN INTRODUction to RISK AND RETURN fRom COMMON 
price movement by repeated trading at a premium above the "uninformed" price. ${ }^{\text {of }}$ Finally, an acquirer must use trading records to establish that that particular insider, and not another trader, was responsible.6s

After an acquirer has shown that insider trading drove up the target share price before public announcement of a takeover, the acquirer must demonstrate that the higher share price caused by insider trading, in turn, led it to pay more for the target. ${ }^{68}$ Empirical evidence demonstrates that acquirers pay a certain percentage of premium above the pre-bid market price rather than absolute dollar figures. ${ }^{67}$ In evaluating a target, an acquirer estimates what premium over the current market price it will have to offer to achieve control. ${ }^{88}$ In addition, studies of takeovers under laws requiring relatively early disclosure have concluded that when information

Srox:ks 17 (2d ed. 1983) (rapid price adjustment to reflect new information does not require widespread dissemination of information).

64. See Gilson \& Kraakman, supra note 44, at 570. Gilson and Kraakman argue that prices come to reflect information which is only available to a small group of market professionals because "a minority of knowledgeable traders who control a critical volume of trading activity" can cause rapid price equilibration. Id. at 569. $\Lambda$ single knowledgeable trader with sufficient resources can bring about price changes by persistent trading at a premium over the "uninformed" price, perhaps by triggering temporary fluctuations in price and volume that alert an uninformed majority to the existence of new information. Id. at 570 n.67. Intermediary employees frequently pass information to artitragers who are likely to be in positions allowing them to exercise such influence. A good example of such a "single informed trader" with large resources was Ivan Boesky. Boesky's financial resources enabled him to buy, based on inside information about impending tender offers, 1,700;000 shares of Carnation Co. (4.9\% of the company, at an approximate cost of $\$ 92$ million) and 817,500 shares of Natomas Co. (1.6\% of the company), to cite just two instances of his market power. Glaberson, Wall St. Informer Admits His Guilt in Insider Trading, N.Y. Times, Feb. 14, 1987, at 1, col. 1; Standard \& Poor's Corp., Daily Stock Price Record NYSE 73 (July/Aug./Sept. 1984); Id. at 292 (Jan./Feb./ Mar. 1983); Id. at 298 ( $\Lambda$ pr./May/June 1983).

65. For example, the Litton complaint alleges that Levine caused to be purchased 50,000 shares of the target, Itek, beginning four days after Litton decided to pursue control of Itek. Second Amended Complaint, at 10-11, Litton Indus. v. Lehman Brothers Kuhn Loeb, Inc., No. 86-6447 (S.D.N.Y. filed Aug. 19, 1986); see supra note 38.

66. In theory, one could argue that acquirers do not spend more if: (1) the target company has an intrinsic value; 2) the acquirer believes it knows this value and will not bid more than a set, absolute price; and 3) because markets are efficient, the acquirer will have to pay this absolute price to buy. The market efficiency theory views auctions for control as a mechanism for moving target share price to its intrinsic value. Since bidding eventually would have pushed the price up to this level, regardless of other factors, the fact that insider trading has caused some price rise is irrelevant. It means only that the difference between the market price and the successful tender offer price-the premium-is smaller, while the ultimate price paid remains the same. Thus, the acquirer would be precluded from showing any damages in a "perfect" market where information is immediately and costlessly available to all. In reality, however, transactions costs prevent perfect information flow, creating opportunities for acquirers to profit from superior information by paying less than the firm's intrinsic value. See Gilson \& Kraakman, supra note 44, at 609.

67. See, e.g., M. Lifion \& E. Strinberger, TAkeovers and Freezeouts 23, 24 (1st ed. 1978). In the late 1960 's, before the takeover wave of the mid-1970's, premiums averaged around $25 \%$ over market share price. In the late 1970's to early 1980's, the average premium rose to near 50\%, and has since declined to 35-40\%. W.T. GrimM \& Co., Mergerstat Review 1985121 (1986).

68. See B. Fox \& E. Fox, supra note 12, I 27.03[2][6] (factors which enter into acquirer's calculation of premium). See generally Greenhill, Structuring an Offer, 32 Bus. LAw. 1305 (1977) (discussing investment bank's role in advising acquirers on hostile tender offer and determining offering price). 
is released earlier (as it is here by insider trading), the acquirer pays a higher premium, whether or not an auction later occurs. ${ }^{60}$

In addition to the acquirer's own calculations, the target's willingness to sell and the ultimate price reached through negotiation are affected by the pre-announcement market price. When an acquirer values an acquisition candidate, it typically combines four indicators-discounted cash flow, prices paid for comparable acquisitions, ${ }^{70}$ the performance of common stock relative to comparable companies, and liquidation analysis (based on the first three measures plus individual valuation of company assets). ${ }^{71}$ With the exception of discounted cash flow, which is based on the net present value of the cash flows generated by the business, each of these methods takes into account market price of target shares. ${ }^{72}$ Thus, a change in market share price will alert a target that it can command a higher premium than the one originally contemplated by an acquirer and encourage defensive tactics in a hostile situation or a tougher negotiating stance in a friendly merger. ${ }^{73}$

69. See Jarrell \& Bradley, The Economic Effects of Federal and State Regulations of Cash Tender Offers, 23 J.L. \& Econ. 371, 373 (1980).

70. Investment bankers review prices paid for companies in similar industries with attributes similar to those of the target, based on data such as W.T. Grimm \& Co., supra note 67, at 126 (1985) (average premiums paid in various industries).

71. See Harris, Determining the Right Price to Pay, in HANDBook of Mrkgkrs, Ac:Quisrnons \& Buyours 150 (S. Lee \& R. Colman eds. 1981); Saffer, Touching All Bases in Setting Merger Prices, Mergirs \& $\Lambda$ couistrions, Fall 1984, at 42-43; Note, supra note 49, at 137-39.

72. For comparable acquisitions, premium comparison involves using market price as a baseline, see supra note 70; for performance of common stock, use of market price is obvious; for liquidation, stock price is incorporated secondarily through its use in the other methods.

73. Some might argue, however, that'acquirers are actually helped rather than hurt by the leak of information through intermediaries, if such leaks are solely to arbitragers. See generally The Place of Arbitrageurs in Mergers and Acquisitions, MrRgers \& AcQuisirions, July/Aug. 1986, at 24. The leaks may move target stock into "friendly" hands. Arbitragers who know about an impending takeover buy up smaller holdings to amass target stock (usually just less than $5 \%$ to avoid filing a Form 13D). When the acquirer eventually makes its offer, the offer may be more likely to succeed because the arbitragers are more willing to sell than other investors. For this reason, some have argued that acquirers impliedly consent to selective leaks by their investment bankers because it is in the client's interest. See Anders, Cloudy Cases: Insider-Trading Law Leads to an Array of Interpretations, Wall St. J., Feb. 19, 1987, at 31, col. 3; Scandal Primer, Wall St. J., Feb. 18, 1987, at 26, col. 1. If there is any significant evidence that the acquirer acquiesced in or intentionally closed its eyes to this kind of tipping, the acquirer would not be entitled to any damages because it would have, in effect, changed the terms of the contract by giving later instructions to its agent. See E.A. FARNSWORTH, supra note $60, \S 4.25$. Without such evidence, the possibility of an acquirer benefitting from intermediary tips should not be an obstacle to recovery for breach of contract. First, the assumption that tipping to arbitragers helps acquirers is debatable. Although an arbitrager may have received information about a certain acquirer, nothing prevents the arbitrager from selling to a competing bidder. In addition, buying by arbitragers tends to drive up the price the acquirer must pay, and, to the extent that blocs are amassed, makes it easier for a competing bidder as well as the original acquirer to succeed. Second, one must ask: Who is likely to bring such suits and how probable is it that these would-be plaintiffs acquiesced in tipping? Initially, acquirers considering filing suit will consult legal counsel who will inquire into any evidence of implied consent to the tipping by the acquirer. If the lawyer discovers such evidence, she will advise the acquirer that its claim is not worth pursuing. The selfselection of plaintiffs will tend to screen out suits by acquiescing acquirers. In addition, those most likely to sue are not professional "raiders" who are more likely to be part of an arbitrage network and would not want to jeopardize their beneficial ongoing relationship with an investment bank, but rather companies who consulted an investment bank on a one-time basis to address a specific corpo- 


\section{B. Damages for Breach of Contract}

Injured acquirers may present two theories on loss entitling them to damages: disgorgement of profits by the inside trader and his tippees ${ }^{74}$ and the fair market value of the exclusive use of their confidential information. Although the disgorgement measure is easy to compute from purchase and sale records, ${ }^{75}$ it has the disadvantages of not placing pressure on firms to improve monitoring ${ }^{76}$ inadequately compensating the acquirer for its lost business opportunity, ${ }^{77}$ and creating problems of multiple recovery. ${ }^{78}$ The better measure of damages, the fair market value of the exclusive use of the information, is the injured party's expectation of the value of the contract-the usual measure of relief for breach of contract. ${ }^{\text {9 }}$

The most common form of relief for breach of contract is the awarding of damages, ${ }^{80}$ measured by the injured party's expectation. ${ }^{81}$ Two measures of damages are important in computing the expectation of injured acquirers: loss in value and "other loss." The loss in value from the defi-

rate need. For example, Litton Industries decided to acquire a company in the defense electronics industry and consulted Lehman Brothers for help. Litton Sues Lehman Brothers, 18 Sec. Reg. \& L. Rep. (BNA) No. 34, at 1237 (Aug. 22, 1986); see supra note 38. These acquirers are likely to be Wall Street outsiders who would not be deterred from litigation by the prospect of rupturing their relationship with an investment bank when they believe they have sustained large losses because of insider trading in target stock.

74. The acquirer would argue that the inside trader should disgorge any gains from the use of the acquirer's information to the acquirer, rather than, as in SEC actions, to the government. Disgorgement of defendant's profits has been applied as a measure of damages for defrauded buyers and sellers under Rule 10b-5 in an increasing number of cases. See R. Jennings \& H. Marsh, Securities RECiULATION 1121 (1982).

75. The court in Elkind v. Liggett \& Myers, 635 F.2d 156 (2d Cir. 1980), viewed the relatively light burden of proof on the plaintiff as an advantage.

76. Disgorgement by the employee of his profits will not directly provide intermediary firms with incentives to improve internal procedures, as will imposing liability on the firm. The firm would suffer only indirect harm to its reputation as a safe repository of client information.

77. The acquirer is not compensated for the loss in value of its business opportunity because the effect on the acquirer of the leak of information through insider trading is much greater than the gain to the insider.

78. The result may be insufficient compensation for all, as the inside trader may be put in the position of owing these same illegal gains (a fixed "pie," to be divided) to other claimants, such as the SEC, injured sellers, or the Internal Revenue Service (IRS). See SEC and IRS Clash over Entitlement to Disgorged Insider Trading Profits, Bus. LAw. UPDate, Nov.-Dec. 1986, at 1 (SEC, investors and IRS clash over entitlement to alleged insider trading profits disgorged in SEC enforcement action where defrauded investors argue that funds are subject of constructive trust for their benefit and cannot be subject to tax lien). Under one view, the acquirer would not have to share these damages with the shareholders of the target who sold to the insiders, who cannot sue because the insiders did not owe them a duty of disclosure. Moss v. Morgan Stanley, Inc., 719 F.2d 5 (2d Cir. 1983) (employee of investment bank retained by acquirer owed no duty to seller of shares of target who sold on open market). But $c f$. Rothberg v. Rosenbloom, 771 F.2d 818, 822 (3d Cir. 1985) (arguably contrary to Moss-insider on either side of proposed transaction violates insider trading rule when he uses confidential information in violation of fiduciary duty owed to corporation).

79. See, e.g., Wallace Steel, Inc. v. Ingersoll-Rand Co., 739 F.2d 112, 115 (2d Cir. 1984).

80. E.A. FARNSWORTH, supra note $60, \S 12.8$, at 838 .

81. The injured party is entitled to recover an amount that will put him in as good a position as he would have achieved had the contract been performed. Id. at 839 . The party's expectation is measured by the actual worth of the performance of the contract to him, taking into account any peculiar circumstances. Id. 
cient performance of services specified in a contract (here, the engagement letter) is the difference between the value to the injured party of the services that were to have been rendered-the facilitation of transactions desired by an acquirer and maintenance of confidentiality of the deal-and the value to the injured party of the services that were actually rendered. ${ }^{\mathbf{g z}}$ The "other loss," which gives rise to "incidental" or "consequential" damages, ${ }^{83}$ includes additional costs incurred after breach in a reasonable attempt to avoid more serious losses. ${ }^{84}$ The increased amount that an acquirer must pay to consummate the deal after the insider trading may be characterized as additional costs paid in an attempt to avoid the loss of aborting the takeover. ${ }^{85}$

An acquirer's recovery may be affected by two common law exceptions to the general principle of recovery based on the promisee's expectations. ${ }^{86}$ First, an injured party cannot recover loss that the party in breach could not have foreseen as a probable result of the breach when the contract was made. ${ }^{87}$ The party in breach, however, need not have foreseen the particular way the loss came about. ${ }^{88}$ Under this test, an intermediary firm need only have foreseen that if one of its agents traded or tipped on the basis of a client's confidential information, breaching the confidentiality agreement, then the client would have to pay more to complete the deal-an easily forseeable consequence. ${ }^{89}$ Second, and more important, an injured party cannot recover for loss in excess of the amount that "the evidence permits to be established with reasonable certainty." may appear difficult to prove, but in recent cases concerning lost business opportunities courts have been willing to allow the injured party an opportunity to offer proof of lost profits. ${ }^{91}$ This change, along with the

82. See id. $\$ 12.9$, at 844 .

83. See id. at 845 .

84. Id.

85. For a description of the nature of this loss, which includes the loss of "sunk costs" of information gathering and lost business opportunity, see supra note 9 and accompanying text.

86. E.A. FARNSWORTH, supra note $60, \S 12.8$, at 841 . The third exception, that the injured party cannot recover damages for loss that he could have avoided, is less important in this context. The only way that an acquirer could avoid the loss of the additional costs caused by insider trading would be by aborting the transaction. By avoiding that loss, however, the acquirer would probably be causing itself even greater loss in the form of lost profits from the missed business opportunity and the loss of any return on its investment.

87. Hadley v. Baxendale, 9 Ex. 341, 156 Eng. Rep. 145 (1854); Restatremenr (SkCOND) of Contractss $\S 351$ (1981).

88. Rrstattemtent (SFCOND) of Contracts \$ 351 (1981); see also Spang Indus. v. Aetna Casualty \& Sur. Co., 512 F.2d 365 (2d Cir. 1975) (subcontractor liable for loss caused by "unforeseen delays").

89. "The party in breach need not have consented, even tacitly, to be liable for the loss ...." E.A. FARNSWORTH, supra note $60, \S 12.14$, at 876 .

90. RESTAtemkint (SkCOND) of Contracis $\$ 352$ (1981); see also E.A. Farnsworth, supta note $60, \S 12.15$. The modern common law trend has been to relax the requirement. Id. $\$ 12.15$ at 881.

91. See, e.g., Lee v. Joseph E. Seagram \& Sons, 552 F.2d 447, 455 (2d Cir. 1977) (lost profits proper measure of damages even if prospective business not yet established); Contemporary Mission, Inc. v. Famous Music Corp., 557 F.2d 918, 927 (2d Cir. 1977) (error not to admit statistical analysis 
greater willingness on the part of courts to allow proof by expert opinion and by complex economic and financial analysis, ${ }^{02}$ will make it easier for an acquirer to pass the "reasonable certainty" test. ${ }^{93}$

Although there are many variables involved, a court can use expert testimony to estimate what portion of the price fluctuation was caused by insider trading. The practice of employing expert testimony in this context would not be unusual. For example, in shareholder derivative suits against officers and directors for self-dealing, courts have relied on expert financial advisors' opinions to determine the proper value of the stock absent the improper conduct. ${ }^{24}$ Similarly, in actions under section 11(e) of the Securities Act of $1933,{ }^{93}$ which provides for express liability for false or misleading statements in a registration statement, the defendant is permitted to contest damages by showing that the drop in stock price was caused by market factors other than the omitted information. ${ }^{96}$ The damages for breach of contract by the intermediary should be based on the number of shares the acquirer eventually obtained in the tender offer or merger multiplied by the effect of the insider trading on the market price of the target shares. ${ }^{97}$

\section{Conclusion}

This Note has argued that acquirers should be able to recover damages from intermediary firms when an employee of the intermediary trades or tips on the basis of the acquirer's confidential information. The contrac-

and expert testimony to show lost royalties due to breach of contract to promote musical composition); William B. Tanner Co. v. WI00, Inc., 528 F.2d 262, 271 (3d Cir. 1975) (damages from breach of contract may be failure to realize expected profit); see also E.A. FARNSWORTH, supra note 60, $\$$ 12.15 , at 886 . This change in the law has been inspired by more liberal rules for proof of prospective profits under the antitrust laws and the rule that a party to an aleatory contract (such as an insurance contract) may recover damages based on the "value of the chance." Id. at 886-88.

92. E.A. FARNSWORTH, supra note $60, \$ 12.15$, at 887 .

93. Cf. Comment, Remedies-Lost Profits as Contract Damages for an Unestablished Business: The New Business Rule Becomes Outdated, 56 N.C.L. RE.v. 693, 695, 723-29 (1978) (accelerating trend to allow lost profit awards for unestablished businesses, fostered by more widespread acceptance of "yardstick" measure of looking at closely comparable businesses, relaxation of opinion evidence restrictions, and growing sophistication of market analysis and business forecasting).

94. See, e.g., State Teachers Retirement Bd. v. Fluor Corp., 566 F. Supp. 945, 954 (S.D.N.Y. 1983) (in nondisclosure case, measure of damages is difference between selling price and fair market value of stock if all material non-public information had been disclosed, determined by jury with aid of expert testimuny). In addition, courts have been more receptive in recent years to allowing recovery for loss of possible profits, see supra note 93, including those from the sale of securities. See, e.g., Plaine v. McCabe, 790 F.2d 742, 751, 753 (9th Cir. 1986) (even though state commission determined merger price was fair, target shareholder may be able to show that had defendants fully complied with securities laws, plaintiff would have obtained higher price for shares).

95. 15 U.S.C. $\$ 77 \mathrm{k}$ (1985).

96. See, e.g., Feit v. Leasco Data Processing Equip. Corp., 332 F. Supp. 544, 585 (E.D.N.Y. 1971) (damage figure should be adjusted to take account of market decline which would have affected any security).

97. For example, if a target's shares were trading at $\$ 10$ before any takeover activity and rose to $\$ 17$ by the time a tender offer at $\$ 22$ per share was announced, a court could determine that $\$ 3$ of the price rise per share was caused by insider trading and $\$ 4$ by other market factors. The acquirer would be entilled to damages of $\$ 3$ multiplied by the number of shares bought in the tender offer. 
tual relationship between an acquirer and an intermediary regarding confidentiality should provide the basis for liability. Allowing acquirers to hold intermediary firms liable will increase incentives for acquirers to undertake searches to identify takeover candidates, resulting in takeovers which may benefit target shareholders through replacement of inefficient managers or the payment of premiums. In addition, such suits promote the deterrence and detection of insider trading by intermediary firms. Elimination of ambiguity surrounding the intermediary's contractual duty regarding confidential client information will propel intermediaries toward the optimal level of internal monitoring. 